\title{
BENEFITS THAT ISLAMIC AND CONVENTIONAL BANKS CAN ATTAIN BY IMPLEMENTING GREEN BANKING
}

\author{
Kashfia Sharmeen ${ }^{1}$ and Ahsan Mahbub Yeaman ${ }^{2}$ \\ ${ }^{1}$ Bangladesh Institute of Capital Market (BICM), Bangladesh, kash.nsu@gmail.com \\ ${ }^{2}$ K\&Y Ventures, Bangladesh, amyeaman.bd@gmail.com
}

\begin{abstract}
This paper aims to ascertain the benefits that Islamic and conventional banks in Bangladesh can reap by implementing green banking, and also the drivers that motivate banks to behave environmentally. The Green Compliance Index (GCI) was introduced here to measure banks' environmental behaviour. It was prepared based on central bank guidelines. In this study, with the participation of all 40 private commercial banks (PCBs), 32 conventional banks and 8 Islami Shariah-based PCBs, firm specific variables were collected through content analysis of the GCI. Structural equation modellingpartial least squares (SEM-PLS), together with the bootstrapping method, were used to evaluate the research data. These were collected and sorted from the FY annual report of 2018. For further support, a Generalized Linear Model (GLM) was used to assess the outcomes. The results show that the effects of green compliance on possible benefits are significantly higher for Islamic banks. In contrast, these banks comply less with the green banking codes than conventional banks do in Bangladesh. Company size and the independence of bank directors appear to have a significant influence on compliance with the green banking codes, while governance does not show such an association for either group of banks. As Islamic banks have a greater scope to attain benefits, policymakers should introduce more interactive green banking products and loan schemes for prospective consumers, especially in industrial sectors where there is a greater possibility of being sustainable and environmentally friendly. Based on the findings, policy recommendations are made for practitioners, regulators and future researchers.
\end{abstract}

Keywords: Green compliance, Climate change, Islamic banks, Conventional banks, Green banking benefits.

JEL Classification: G20; G21; Q5.

\author{
Article history: \\ Received : October 31, 2019 \\ Revised : August 27, 2020 \\ Accepted : September 1, 2020 \\ Available online : November 25, 2020
}

https://doi.org/10.21098/jimf.v6i4.1134 


\section{INTRODUCTION}

\subsection{Background}

The existence of the atmosphere is shared by all global commons, both developed and developing countries, and no nation can escape the worsening warming effects of the global climate crisis. Many obvious and negative results of climate change are being experienced in the form of rising sea levels, intense heatwaves, shrinking glaciers, floods, tsunamis and changes to the range of plants and animals. "These outcomes threaten sustainable living in this planet which calls for an urgent and collective response from both developed and developing countries" (Miah \& Rahman, 2018, p. 23).

The adverse consequences of climate change require a serious and united response from both industrialised and advanced, as well as emerging countries (Sharmeen et al., 2019). The response to climate change effects involves radical changes in how global economies, together with daily life, are organised. Greenhouse gases (GHGs) are emitted in production and consumption processes. Therefore, accelerated national action is crucial in order to change modes of production and consumption by transforming technologies, implementing this at various levels of the economy.

Financial institutions such as banks are in a strategic position to play a pioneering role in creating and maintaining a green revolution for the planet. "These institutions can implement a 'go-green' policy for themselves and can encourage client firms for the same by initiating various incentive mechanisms" (Sharmeen et al., 2019, p. 735). As banks play a considerable role in financing commercial projects for organisations, the 'green' concept has enormous potential. Green finance means that investments are only made in projects in which the emission of greenhouse gases is minimal, and the carbon footprint is transparent. By pursuing this strategy, banks can motivate their existing and potential clients to undertake environmental cooperative projects. Although this initiative might increase customers' operational and production costs marginally, the long-term effects will be in the banks' favour. Therefore, in terms of banking activities, green banking involves extra care for the planet's ecosystem, atmosphere and natural resources (Islam et al., 2014).

Bangladesh, being at the development stage, needs green banking activities far more, as it has a higher level of vulnerability to the hostile consequences of climate change. It is trying harder and harder to increase its GDP so that the densely populated country can fight against the poverty of its low-income citizens. The Bangladesh Bureau of Statistics (BBS) stated that the country had achieved success in improving its GDP over the last few years (BBS, 2014). Being financial bodies, banks play a critical role in contributing to the financial success of the country. Hasan and Miah (2018, p. 135) state that "a booming banking sector successfully adjusted and supplied required funds for increased investment activities accelerated by the rising income of the middle class and along with that they are proposing new but striking loan products to their clients". As a result, this segment is having a considerable effect on the on-going sustainable environmental movement in the country through the introduction of 'green' banking practices (Hasan \& Miah, 2018).

Despite very worthy endeavours from the national government and international development agencies, the movement towards green banking 
activities has not advanced as quickly as it should have. This can be attributed to many reasons, including lack of awareness of green banking on the part of banks and their client firms. However, the main cause of this behaviour by banks can be attributed to their excessive focus on profit and their failure to realise the benefits of going green.

In the case of Bangladesh, conventional banks dominate the overall financial system. However, according to some research findings, Islamic banks are steadily growing and taking a large share of the sector. Although profit is a primary motive for both types of bank, Islamic banks are expected to be also concerned with satisfying the social purposes of justice in line with Shari'ah. Shari'ah principles dictate that Islamic banks have an ethical and holy obligation to be environmentally concerned (Suzuki \& Miah, 2016). It is argued that asset managers' quest for a balance between moral and Shariah-compliant investing, renewable financial products and ecological agriculture is developing in Islamic investment (Vizcaino, 2014). Moreover, Shariah principles give Islamic banks a competitive advantage in the area of green compliance, as Islamic rules and regulations focus on the development of the community. Therefore, it can be expected that Islamic banks will be more concerned about the environment than their conventional counterparts. This research is an attempt to examine this hypothesis.

Although it is timely and a pragmatic issue, the research gap related to this aspect is very limited worldwide and more so in the case of Bangladesh. Very few studies have focused on this issue in the context of Bangladesh, and their results are conflicting. For instance, Ali and Rahman (2015) found in the 2013 annual reports of five commercial and Islamic banks in Bangladesh that in terms of the environmental dimension of CSR activities, the banks' efforts were similar. This finding contradicts the results of Chintaman (2014), who showed that in the context of the GCC region, Islamic banks undertook CSR activities more creatively, while conventional banks were only on par with to Islamic banks regarding CSR practices. Later, Sharmeen et al. (2018) attempted to establish some of the underpinning advantages that can be derived from executing green banking parameters in the moral ground, especially in Islamic banking in Bangladesh.

\subsection{Objectives}

This study, therefore, is an effort to present the current status of green initiatives by banks in Bangladesh and to observe whether Islamic banks are gaining more benefits than conventional banks by implementing green banking, and if so, what these are. The research further seeks to explain the existing institutional frameworks enacted to restrain and encourage banking institutions to behave environmentally. As there is a dearth of research in this area, the findings of this research will help regulatory authorities and policymakers to formulate policies to increase the focus on the banking sector. The motive is unambiguous and clean. Banks, as the core profit-making financial institutions, are not willing to spend money on green issues which will not directly contribute to revenue generation. If it can be shown that banks will attain benefits by implementing green issues, they will more readily comply with sustainable environmental conditions directed by the central bank, and subsequently, be encouraged to act accordingly. 


\section{LITERATURE REVIEW}

\subsection{Background Theory}

"While the risks of climate change for South Asia emerge as quite serious, the risks and impacts for Bangladesh are arguably amongst the highest in the region" (World Bank, 2013). This study refers to Bangladesh as a potential hotspot which is projected to face serious natural disasters. Considering long-term sustainable development will be the best option for the developing country to deal with these. The sustainable development concept, which focuses on 'conserving the earth's natural resources' (Amacker, 2011), can be undertaken by reducing the carbon footprint at the individual, organisational level. To work with the risk of climate change, more attention needs to be paid to attaining environmental sustainability, which is one of the vital three pillars of sustainability (the triple bottom line concept) and which emphasises maintenance of the quality of our surrounding environment (Klarin, 2018). To achieve long-term environmental sustainability, financial institutions can play a crucial role by taking green finance seriously.

It is anticipated by the World Bank (2010) that "a sea-level rise of one meter is expected to affect 13 million people in Bangladesh". In response, the Bangladesh government, other regulators and banks, have formulated and implemented substantial environmentally-friendly policies (Bose et al., 2018). As banks hold a large share of the financial sector's assets (Zadek \& Robins, 2015), the central bank of Bangladesh is continuously developing guidelines to comply with the 'green' concept.

Recent trends in green financing in Bangladesh "reveal that so far, 55 banks out of 56 have taken green banking programs by establishing green banking unit" (BB, 2016). According to a Bangladeshi bank report (2017), a total amount of $\$ 2022.85$ million had been invested as green finance during the October-December quarter of FY17 by all banks. In terms of the focus on sector-wise input, it was shown that private commercial banks played the key role (80.9 percent).

Many studies show that intervention by the central bank has a strong positive impact on the implementation of green banking (Ramnarain \& Pillay, 2016; Oyegunle \& Weber, 2015). To comply with the process and to motivate banks to go green, the Bangladeshi government has proposed various benefits to the country's banking sector (Oyegunle \& Weber, 2015). For example, at the beginning of 2016, a new refinancing scheme called the Green Transformation Fund (GTF) of BDT 17,000 million (approx. \$200 million) was implemented to ensure the sustainability in export-oriented textile and leather sectors, with BDT 3,413.63 million (approx. $\$ 40.43$ million) spent up to December 2017 under the revolving "Refinance Scheme", which gives a $5 \%$ window on loan interest premiums for commercial banks (Bangladesh Bank, 2017).

Along with conventional banks, Islamic-based shariah banks can enjoy the benefits of this scheme. BB distributed BDT 52.00 million (approx. \$0.62 million) for the "Working Environment and Fire Safety of Factories under a shariahbased refinancing scheme during October-December, 2017 quarter and has also has collected BDT 0.50 million profit under this scheme" (BB, 2017). Four Islamic banks agreed to create investing renewable energy and reinforce the involvement of shariah-based financing (BB, 2017). 
However, regulation cannot guarantee the full phase compliance by banks. Bose et al. (2018) found pragmatic evidence that implementing green banking is more than a routine procedure as time passes, but instead becomes more innovative. Therefore, it is essential to motivate banks towards green compliance by showing the positive outcomes and other benefits (Laskowska, 2018; Oyegunle \& Weber, 2015; Lalon, 2015). It has also been observed that banks who adopt a sustainability strategy "consistently outperform in terms of valuation, profit/loss and return on equity (ROE)" (Ramnarain \& Pillay, 2016; Straw, 2013; Eccles et al., 2011). Global Systemically Important Financial Institutions (GSIFIs) propose five significant benefits for green banks in having better coverage of clients in terms of attracting deposits and offering loans, which eventually lead to higher growth in assets and income, and better returns on assets (as cited in Ramnarain \& Pillay, 2016).

Besides, Laskowska (2018) identified two essential benefits of the green banking sector: lucrative benefits "for the economy and nature where banks can make a profit and also be cost-effective in a long-term perspective". Laskowska gave an example of small and medium companies who are recipients of PolSEFF and receive investment premiums (10\% or $15 \%$ PolSEFF financing) when projects are based on renewable energy sources. In a similar vein, Hossain and Kalince (2014) claim that green banking has a positive influence on banks' enactment and profitability after tax and will create sustainable growth in the long run.

Moreover, to attract major investors who are struggling with the conventional banking system, Benedikter (2011) suggests shifting more to social banking, where "most of them are in search of a better perspective of transparency and reliability". Papastergiou and Blanas (2011) indicate several effective reasons why more banks are pursuing green environmentally-friendly banking systems; for example, they had a "higher reputation and branding, improved the quality of a bank's portfolio and lowered insurance liabilities and compensation allege". Besides, regarding Greek banks, they claimed that the benefits of being ecological outweighed the costs. Likewise, Indian banks also implement green policies, which lead them to win-win situations by helping them to raise their productivity and to reduce costs (Yadav \& Pathak, 2013).

In line with the above discussion, this study considers that if more vital benefits can be presented to commercial banks, policymakers will definitely be able to implement more green banking. Hence, one of the objectives of this study is to demonstrate the particular benefits (see Figure 1) that both conventional and Islamic banks will receive by complying with the green compliance index and whether there are any significant differences between the two types of bank. Another objective is to establish the research gap between the circulation of BB green banking compliance guidelines and the extent to which banks (both conventional and Islamic) comply with the on-going practices. One additional noticeable impact of this research, which considers governance frameworks and firm-specific variables (discussed later) as antecedents of banks' environmental performance and will show the level of the positive (or negative) influence of governance and firm-specific variables on the extent of green compliance. 


\subsection{Previous Studies}

Developed countries are more provoked to environmental deprivation, and therefore countries such as Bangladesh should focus more on sustainable development. Banks can contribute to developing a healthy environment by mostly financing eco-friendly projects and by limiting investments in polluting industries. To achieve optimal results, banks' commitment to internal practices such as the use of efficient electronic gadgets, energy-saving mechanisms, recycling of paper, and limiting the use of energy and water needs to be established within organisations.

Green banking in Bangladesh can help achieve a strong reputation and alertness of all parties in financial sectors by adopting green products such as solar and renewable energy, solid and liquid waste management, biogas plants, and emission-free brickfields. The banking sector in Bangladesh is already contributing to the environment in both internal and external ways. Internally, banks have reduced their carbon footprint by using less paper by offering online and mobile banking, by using energy-efficient cooling and lighting systems and reusing water and other products.

"All 47 banks (as of 2013) have their own Green Banking Policy Guidelines approved by their respective Board of Directors/Competent authority as well as have Green Banking Unit (GBU) for pursuing Green Banking activities. They also have their own Green Office Guide for conducting in-house green activities" (Bangladesh Bank Report, 2015). 43 banks have introduced a full range of green finance services, directly (38 banks) or indirectly (30 banks). BDT 0.127 million (about USD 1497.07) was disbursed in the April-June 2018 quarter.

For our research, all 32 conventional banks and eight Islamic banks have been considered. The policy guidelines for green banking suggested by the Central Bank consist of various sections, which we have incorporated into seven categories. A comprehensive assessment was made to ascertain the green compliance of the 32 private commercials and eight Islamic banks with the seven green banking guidelines (Appendix I).

According to our analysis, around $87 \%$ of banks, both Islamic and commercial, have already established individual green banking cells and policies, and have regularly published brief information in their annual reports. The remaining 13\% are in the process of doing this. Private commercial banks are at the forefront compared to Islamic banks in framing policies and governance. 59\% of Islamic banks comply with obtaining board/regional head approval for green banking policies, while more than $70 \%$ PCBs comply with this. An interesting observation is that the amount of funds received from BB for green banking purposes is higher for Islamic banks. However, fund allocation for green banking, utilisation of funds and formation of green banking units are superior in conventional banks in Bangladesh.

The question of morality should also be an issue for Islamic banks, which are encouraged more to adopt green practices for a better future compared to conventional banks. From our observations, we have seen that ethical ground employs here in more of paperwork rather than from the internal drive. 


\section{METHODOLOGY}

\subsection{Data}

Currently, 59 scheduled banks are operating in the country, which is categorised as state-owned specialised banks, private commercial ones, Islamic and foreign banks. Due to the differences in reporting standards (for foreign banks) and the purpose of operations (specialised and state-owned commercial banks), these two categories were not included in the study, which left a sample of 40 private commercial banks, out of which 32 were conventional and eight Islami Shariahbased PCBs. According to the Bangladesh Bank, these commercial banks hold 52.12 percent of the overall deposits of the banking industry, which makes them an appropriate representation of the total population. The data were collected from FY 2018 annual reports in order to acquire governance and firm-specific information..

\subsection{Model Development}

As discussed earlier, sustainable development can be achieved by implementing green policies, with development coming from two core reinforcements governance and firm-specific needs. In our research, we considered the above three parameters as the 'causes' behind green banking compliance for scheduled banks in Bangladesh. These causes emphasise the active co-operation between them and the mediator, the green compliance index (GCI), in creating a viable business which eventually provides results, for example, accountability, profitability, reputation and moral ground, in the form of comprehensive benefits from complying with green banking.

\section{a. Governance Variables}

Board size and the number of independent directors were considered to represent firm governance. It was assumed that a large board would be more united and more devoted to the environment. Studies have shown that for this reason, large boards are under more regulatory surveillance and more pressure to act ecologically (Brown \& Deegan, 1998; Patten, 2002). In certain countries, a large board size is positively related to better performance (Malik et al., 2014). In other cases, wellstructured boards perform well in shareholding monitoring and control (Shakir, 2008).

Independent directors (INDs) are another significant variable which has been increasingly used in recent studies, many of which have shown that INDs can act with less bias, make independent judgments of all operations of a firm, and are more committed to CSR activities (Forker, 1992, De Villiers et al., 2011; Uyar et al., 2013). Therefore, the following hypotheses were formulated:

H1: Governance has a positive association with green compliance.

H1a: Board size has a positive association with green compliance.

H1b: The number of independent directors on a board has a positive association with green compliance. 


\section{b. Firm-Specific Variables}

In this model, the firm size was measured by the value of total assets, age and leverage, which were considered for the evaluation of firms' specific needs. "Green innovators are usually larger (in terms of size), older, and significantly more engaged in R\&D spending" (Amore et al., 2015). Firms which have more access to capital are more capable of 'going green'. When a firm has less debt, it can dedicate more to CSR activities (Purushothaman et al., 2000). Based on these facts, the following hypotheses were formulated:

H2: Firm-specific variables have a positive association with green compliance.

H2a: Age has a positive association with green compliance.

H2b: Board size has a positive association with green compliance.

H2c: Leverage has a positive association with green compliance.

\section{$\begin{array}{lll}\text { Cause } & \text { Mediator } & \text { Results }\end{array}$}

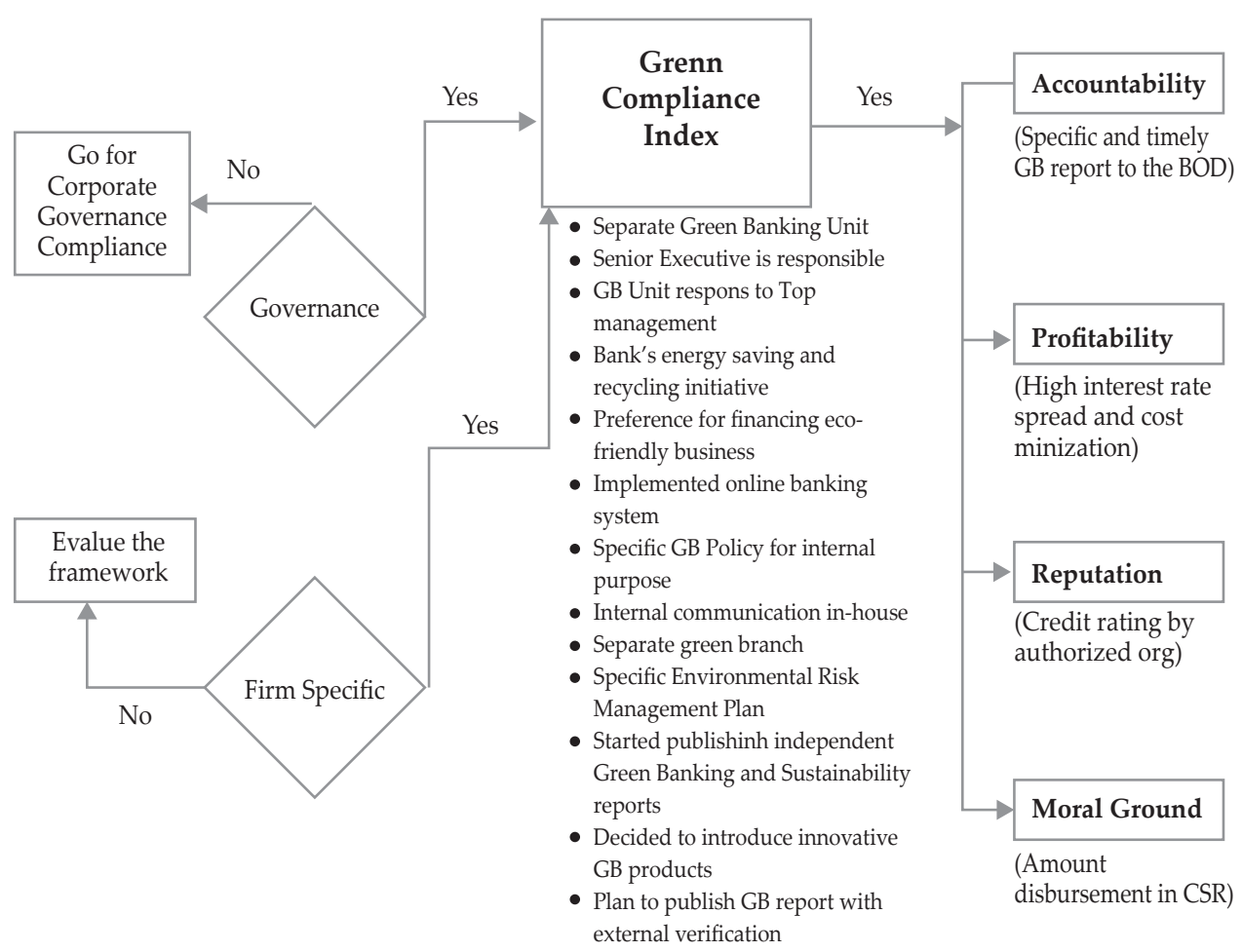

Figure 1.

Underpinning and Benefits of Green Banking Compliance

\section{c. Green Compliance Index}

In the model, the Green Compliance Index (GCI) works as a mediator. From 2011 to 2014, the central bank provided green banking policies for all commercial banks, in which thirteen requirements (see Figure 1, Mediator column) were considered 
for the compliance index (Appendix II, Green Compliance Index Survey results). As such, the extent of green compliance is measured through content analysis by using a self-developed index following Bangladesh Bank guidelines. A score of 1 is given to banks that comply with items on the index, and 0 otherwise. The sum of the scores for all items is divided by the number of items. Therefore, a bank's green compliance index will range between 0 and 1 (Appendix II). The green compliance index was sent to the head offices of all forty banks to obtain information. Information on all the other variables was gathered from the annual 2018 reports. Four benefits of green compliance were identified, namely accountability, moral ground, reputation and profitability. According to our research, the underlying benefits of complying with green banking come with efficiency, accountability, profitability, innovation, reputation and moral ground.

Accountability: Another important benefit for banks is accountability from complying with GCI. In this paper, we measure the accountability of banks who submit reports on time to the authorities. Under Phase II, Bangladesh Bank requires the disclosure and reporting of green banking activity for all commercial banks (Bangladesh Bank, 2012).

Profitability: Another independent variable is profitability, which can be derived by implementing green in the financial sector. Through reinvestment schemes, firms receive subsidies on interest when issuing loans, and green banking also reduces operational costs by reducing the carbon footprint and recycling waste (Jeucken, 2001; Nath, 2014; Ginovsky, 2009). We have calculated increase profitability for getting more interest rate spread and also cost minimisation.

Reputation: Financial institutions which emphasise being green rather than simply on profit-making activities create a long-term impression in the eyes of stakeholders (Neu et al., 1998). It has been found that banks' commitment to CSR leads to better credit rating scores. Banks which are good at managing risk are considered reputable in society. As such, banks' credit rating scores are regarded as a proxy for reputation.

Moral ground: In this research, the moral ground was measured by the amount disbursed on CSR activities by scheduled banks, with a positive relationship between bank morality in the eye of stakeholders and GCI expected. In Bangladesh, the direct and indirect budgetary CSR commitments of banks and financial institutions have increased considerably since 2008. The increasing level of financial involvement in CSR has raised concerns about the appropriate allocation of funds in environmental projects by concerning commercial banks (Bangladesh Bank CSR report, 2015). The above discussion, therefore, leads us to the following hypotheses:

H3: Green compliance has an affirmative connotation with expected benefits.

H3a: Green compliance has an affirmative connotation with accountability.

H3b: Green compliance has an affirmative connotation with the moral ground.

H3c: Green compliance has an affirmative connotation with profitability.

H3d: Green compliance has an affirmative connotation with reputation. 


\subsection{Method}

The study includes four variables. First, the governance and firm-specific variables are independent ones that affect the extent of green compliance in the selected banks. The level of governance is measured by board size and the number of independent directors on the board. Firm-specific variables include age, size and gearing. The degree of green compliance is also used as both an independent and dependent variable to predict the benefits generated through an extensive literature review.

Table 1.

Variable Definition

\begin{tabular}{ll}
\hline \multicolumn{1}{c}{ Variable } & \multicolumn{1}{c}{ Definition } \\
\hline Independent Only & \\
\hline Board Size (BS) & Total number of directors on board. \\
Independent Directors (IND) & Total number of independent directors on board. \\
Age & Number of years the bank has been operating. \\
Size & Natural logarithm of total assets. \\
Gearing & Total liabilities divided by total equity. \\
\hline Both Dependent and Independent & \\
\hline P1 for first level & Total score for first level substances. \\
P2 for second level & Total score for second level substances. \\
P3 for third level & Total score for third level substances. \\
Dependent Only & \\
Profitability & Net profit divided by total assets. \\
Accountability & 1 when a bank makes a distinct green compliance statement \\
Moral Ground & for its board. \\
Reputation & Natural log of CSR expenditure. \\
\hline
\end{tabular}

A Structural Equation Modelling - Partial Least Squares (SEM-PLS) approach was applied to analyse the above data, employing Smart PLS 3.0 to measure the statistical significance of the model and the acceptability of the developed hypotheses. PLS is a widely accepted method to test the reliability and validity of a theoretical model (Becker \& Ismail, 2016). It has been primarily used for models with latent variables. However, evidence exists that indicates that SEM-PLS can also be used with secondary data-based models. We used the bootstrapping method (with 200 resamples) to determine the significance levels of the loadings, weights and path coefficients (Chin, 1998; Gil-Garcia, 2008). An additional validity test and regression analysis were conducted in SPSS 23. 


\section{RESULTS AND ANALYSIS}

\subsection{Results}

Among the total 40 selected banks, 32 were conventional and eight Islamic. The highest standard deviation was seen in the age of the banks, which indicates diversity in the sample regarding experience. A few of the commercial banks were founded in the last four years, while most started operations in the 1980s. A low level of standard deviation in one of the benefits, with profitability indicating that the level of return among the banks was similar.

Table 2.

Descriptive Statistics of the Selected Sample

\begin{tabular}{lcccccccccccc}
\hline & BS & IND & AGE & Gearing & Size & P1 & P2 & P3 & Acc & ROA & MG & Rep \\
\hline Mean & 14.000 & 2.000 & 22.640 & 12.381 & 25.867 & 0.850 & 0.651 & 0.590 & 0.900 & 0.006 & 17.905 & 3.150 \\
Median & 14.000 & 2.000 & 19.000 & 12.335 & 26.288 & 0.857 & 0.800 & 0.500 & 1.000 & 0.007 & 18.524 & 4.000 \\
Std. Dev. & 4.142 & 1.076 & 13.542 & 5.393 & 1.049 & 0.157 & 0.176 & 0.360 & 0.307 & 0.016 & 3.265 & 1.368 \\
Skewness & -0.070 & -0.267 & 0.673 & -0.056 & -1.311 & -1.023 & -0.785 & -0.286 & -2.726 & -1.561 & -4.544 & -0.943 \\
Kurtosis & -1.141 & -0.034 & 0.476 & 1.638 & 1.120 & 0.280 & -0.581 & -0.979 & 5.722 & 10.465 & 24.812 & 0.090 \\
\hline
\end{tabular}

\section{a. Collinearity Statistics (VIF)}

A variance inflation factor (VIF) was tested to detect whether or not the predictors were correlated with each other in the model. Ringle et al. (2015) argue that a VIF of less than 5 is acceptable. In this case, all the indicators are valid, and the variance in their particular coefficients would expect to have no multicollinearity; i.e. there is no correlation with other predictors.

Table 3.

Collinearity Statistics (VIF)

\begin{tabular}{llll}
\hline \multicolumn{1}{c}{ Indicator } & VIF & \multicolumn{1}{c}{ Indicator } & VIF \\
\hline BS & 1.109 & P2 & 1.415 \\
IND & 1.109 & P3 & 1.159 \\
Age & 1.439 & Accountability & 1.651 \\
Gearing & 1.347 & Profitability & 1.430 \\
Size & 1.825 & Profitability & 1.430 \\
P1 & 1.252 & Moral Ground & 2.178 \\
\hline
\end{tabular}

\section{b. Measurement Model}

The reliability of the contents of the self-developed green compliance index was checked with Cronbach's alpha. "An alpha value greater than seventy percent works as a rule of thumb to prove the reliability and consistency of the developed instrument" (Tavakol \& Dennick, 2011; Nunally, 1978; Nunally \& Bernstein, 1994; Hair et al., 2010; Urbach \& Ahlemann, 2010). Table 4 shows the alpha values (Hair et al., 2010) for the whole model. Firm-specific, green compliance and benefits proved their reliability, with alpha values of $0.721,0.853$ and 0.791 respectively, while governance failed to cross the seventy percent threshold. 
A two-step approach was used to test the validity of the measurement model, following the suggestions of Anderson and Fornell (2009). First, convergent validity was assessed based on the information provided in Table 4. "Convergent validity can be ascertained if the loadings are greater than 0.50" (Bagozzi \& Yi, 1991; Nunally, 1978; Hair et al., 2010); if composite reliability is greater than 0.70 (Gefen et al., 2000; Hair et al., 2010; Fornell \& Larckel, 1981) and if the average variance extracted is greater than 0.50 (Fornell \& Lacker 1981; Hair et al., 2010; Urbach \& Ahlemann, 2010; Barclay et al., 1995). Moreover, CR provided higher bound values which did not underestimate the true reliability or exaggerate the consistency of the outer loadings, which is the case with Cronbach's alpha (Peterson \& Kim, 2013). Based on the selected criteria, the construct reliability and validity of the whole model is consistent, whereas the loading and composite reliability of governance was affected.

Table 4.

Construct Reliability and Validity

\begin{tabular}{llcccc}
\hline Parameter & \multicolumn{1}{c}{ Measurement items } & Loading & $\begin{array}{c}\text { Cronbach's } \\
\text { alpha }\end{array}$ & CR & AVE \\
\hline Governance & Board Size & 0.387 & 0.477 & 0.691 & 0.572 \\
& Independent Directors on Board & 0.922 & & & \\
(BS) & & & & \\
Firm- Specific & Age & 0.750 & 0.721 & 0.830 & 0.623 \\
& Gearing & 0.721 & & & \\
Green & Size & 0.911 & & & \\
Compliance & Level 1 (P1) & 0.808 & 0.853 & 0.747 & 0.506 \\
& Level 2 (P2) & 0.785 & & & \\
Benefit & Level 3 (P3) & 0.511 & & & \\
& Accountability (ACC) & 0.997 & 0.791 & 0.817 & 0.549 \\
& Moral Ground (MG) & 0.946 & & & \\
& Profitability (ROA) & 0.564 & & & \\
\hline
\end{tabular}

Discriminant validity was tested using the Ringle and Sarstedt (2015) and Fornell and Lacker (1981) criterion. Based on the results provided in Tables 4 and 5 , we found that the correlations for each construct were less than the square root of the average variance extracted (AVE), which indicates adequate discriminant validity, apart from a single path from governance to benefit in the heterotraitmonotrait ratio. As the construct has the strongest relationships with its own all other indicators in the PLS path model (Hair et al., 2017), it was kept in the model for further analysis. 
Table 5.

Discriminant Validity of the Constructs

\begin{tabular}{lcccc}
\hline \multicolumn{1}{c}{ Construct } & Governance & Firm- Specific & Green Compliance & Benefits \\
\hline Governance & 0.756 & & & \\
Firm-Specific & 0.552 & 0.789 & & \\
Green Compliance & 0.342 & 0.366 & 0.711 & \\
Benefits & 0.572 & 0.552 & 0.381 & 0.741 \\
\hline
\end{tabular}

\subsection{Robustness Test}

The structural model was tested using SMART PLS 3.0 and bootstrapping with 200 resamples. Figure 2 and Table 6 show the results. The adjusted $R^{2}$ values ranged from 0.145 to 0.463 percent, which suggests that the modelled variables can explain 14.50 to 46.30 percent.

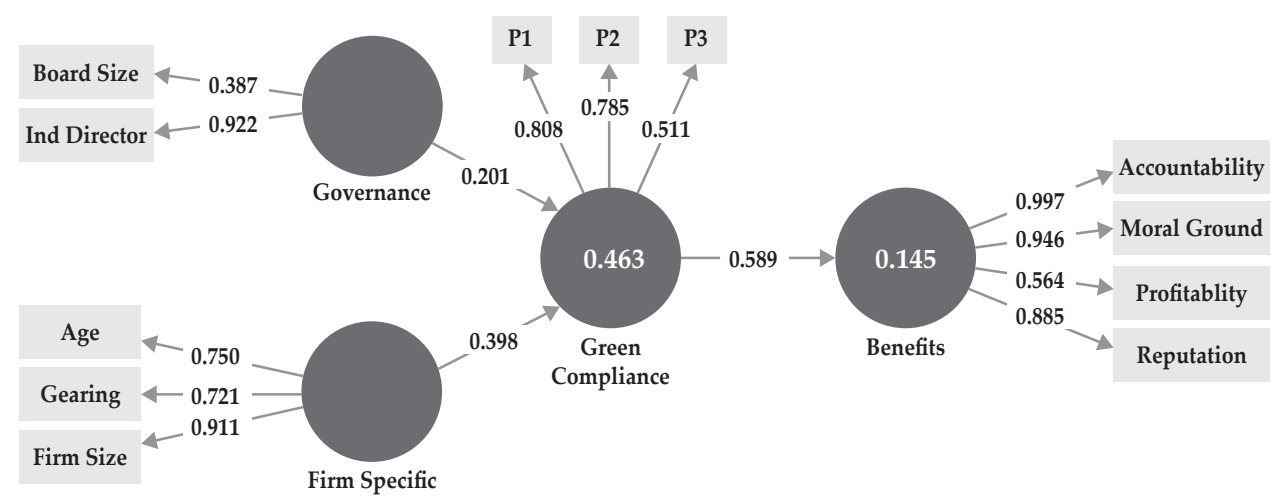

Figure 2.

Structural Equation Modelling Results

Table 6 shows the results of the path coefficient and hypothesis tests. Among the indicators of the firm-specific variable, size has the most significant influence on the extent of green compliance, with a factor loading of 0.911 . The extent of green compliance has a significant influence on accountability (0.997), moral ground (0.946) and reputation (0.885), with higher loadings than profitability (Figure 2 and Table 4). Governance was not found to have a significant association with green compliance among the banks. However, the number of independent directors has the second-highest factor loading of 0.997.

Additional statistical tests were conducted with IBM SPSS 23 to justify another claim. First, multiple linear regression analysis was performed to determine the association between green compliance and benefits, along with board size, number of independent directors, age, leverage and size. The results, shown in Table 7 strengthen our claim, as size $(\beta=.767$, $\mathrm{t}$ - value $=3.715, \mathrm{p}<.05)$ is the most 
Table 6.

Path Coefficients and Hypothesis Testing

\begin{tabular}{|c|c|c|c|c|c|c|}
\hline \multirow{2}{*}{ Hypothesis } & \multirow{2}{*}{ Parameter } & \multicolumn{3}{|c|}{ All Banks } & \multirow{2}{*}{$\begin{array}{c}\text { Conventional } \\
\text { Coefficient }\end{array}$} & \multirow{2}{*}{$\begin{array}{c}\text { Islamic } \\
\text { Coefficient }\end{array}$} \\
\hline & & Coefficient & t-value & p-value & & \\
\hline H1 & Governance -> Green Compliance & 0.201 & 0.908 & 0.364 & 0.165 & 0.116 \\
\hline $\mathrm{H} 2$ & $\begin{array}{c}\text { Firm-Specific -> Green } \\
\text { Compliance }\end{array}$ & 0.398 & $2.354^{* *}$ & 0.015 & $0.432^{* *}$ & 0.189 \\
\hline H3 & Green Compliance -> Benefits & 0.589 & $2.627^{*}$ & 0.004 & $0.653^{*}$ & $0.702^{*}$ \\
\hline
\end{tabular}

significant predictor of green compliance of the selected banks. Likewise, the number of independent directors was found to be a significant parameter in all three scenarios. Among the benefits, accountability emerges as an important factor for all banks and selected conventional banks.

Table 7.

Regression Results

\begin{tabular}{|c|c|c|c|c|c|c|c|c|c|c|}
\hline \multirow{2}{*}{$\begin{array}{c}\text { Independent } \\
\text { Variable }\end{array}$} & \multirow{2}{*}{$\begin{array}{c}\text { Dependent } \\
\text { Variable }\end{array}$} & \multicolumn{3}{|c|}{ All Bank } & \multicolumn{3}{|c|}{ Conventional Bank } & \multicolumn{3}{|c|}{ Islamic Bank } \\
\hline & & Coefficient & $\mathrm{t}$-value & Sig. & Coefficient & $t$-value & Sig. & Coefficient & $t$-value & Sig. \\
\hline $\begin{array}{l}\text { Green } \\
\text { Compliance }\end{array}$ & Acc & 0.426 & $2.868^{*}$ & 0.007 & 0.476 & $2.918^{*}$ & 0.007 & 0.614 & 1.904 & 0.106 \\
\hline $\begin{array}{l}\text { Independent } \\
\text { Director }\end{array}$ & $\begin{array}{l}\text { Green } \\
\text { Compliance }\end{array}$ & .791 & $2.952^{* *}$ & .023 & .861 & $3.042^{*}$ & .003 & .695 & $2.50^{* *}$ & .038 \\
\hline Size & $\begin{array}{l}\text { Green } \\
\text { Compliance }\end{array}$ & .767 & $3.715^{*}$ & .000 & .803 & $4.158^{*}$ & .000 & .369 & 1.86 & .067 \\
\hline
\end{tabular}

**P<0.05; ${ }^{*} \mathrm{P}<0.01$

Multivariate analysis using a general linear model (GLM) was then conducted to determine the association between green compliance and desired benefits included in the structural model. The multivariate test results, shown in Table 8 match the PLS results, as green compliance, is found to have a significant positive association with a reputation $(\beta=2.384, \mathrm{p}<.05)$, accountability $(\beta=4.619, \mathrm{p}<.05)$ and moral ground $(\beta=9.591, \mathrm{p}<.05)$.

Table 8.

Multivariate Tests

\begin{tabular}{clccc}
\hline $\begin{array}{c}\text { Independent } \\
\text { Variable }\end{array}$ & \multicolumn{1}{c}{$\begin{array}{c}\text { Dependent } \\
\text { Variable }\end{array}$} & $\begin{array}{c}\text { All Banks } \\
\text { Coefficient }\end{array}$ & $\begin{array}{c}\text { Conventional } \\
\text { Coefficient }\end{array}$ & $\begin{array}{c}\text { Islamic } \\
\text { Coefficient }\end{array}$ \\
\hline Green Compliance & Profitability & 1.407 & .955 & 10.33 \\
& Reputation & $2.384^{* *}$ & 1.285 & $2.965^{*}$ \\
& Accountability & $4.619^{*}$ & $4.896^{*}$ & $3.127^{* *}$ \\
& Moral ground & $9.591^{*}$ & $4.776^{* *}$ & $35.193^{*}$ \\
Adjusted R2 & & .781 & .774 & .969 \\
\hline
\end{tabular}

** $\mathrm{P}<0.05 ;{ }^{*} \mathrm{P}<0.01$ 


\subsection{Analysis}

The three-tier analysis was conducted to investigate the existence of a moderation effect of the nature of the bank in the context of green compliance. First, the developed structural model was run twice in SmartPLS 3.0 by splitting the file into two, containing only conventional or only Islamic bank data. The loadings of each construct changed, and in the model, two paths were found significant. One path was from green compliance to benefits, which remained significant for both conventional and Islamic banks, and the other was from firm-specific to green compliance, in which only conventional banks were significant. The loading scores for both models are shown in Table 6.

The second part of the analysis consisted of running regression analysis for selected cases, first for conventional and second for Islamic banks, to determine any difference in the results between the association of governance and firmspecific components and green compliance. The regression results shown in Table 7 are very different for the two different types of bank. While size remains the most significant predictor of green compliance following the results of the selected conventional banks, the presence of independent directors was found to affect green compliance for the overall model, including for Islamic banks. The interesting point was that no positive association was found between board governance and green compliance. In contrast, the presence of independent directors on boards had a positive influence on both types of bank. Therefore, the possible moderation of the nature of the bank needs to be tested.

A test of the difference in slopes was conducted for moderation analysis (Lowry \& Gaskin, 2014). Possible moderation of the bank nature was tested for each path by putting the bootstrapping results into an Excel macro taken from the StatWiki website (Gaskin, 2016). Table 9 shows the results of the moderation tests. The paths from green compliance to benefit and from firm-specific to green compliance were found to be significantly different, which indicates positive moderation of the nature of the bank. This implies that the effects of green compliance on possible benefits are significantly higher for Islamic banks than for conventional ones. This claim is further supported by the multivariate test results shown in Table 8, where it can be seen that Islamic banks benefit more in terms of reputation and moral ground. At the same time, the reverse scenario is true for accountability.

Besides, the f square (effect size) value in Table 9 is fairly consistent with the mediating results, which measure the strength of each predictor variable in explaining the endogenous variables of the model. Only the path from green compliance to benefits has a moderate effect (f square $=0.17$, which is greater than 0.15), whereas the other two paths indicate a weak effect (less than 0.02) (Chin, 1998; Cohen,1988; Hair et al., 2014).

Table 9.

Difference in Slope Test for Mediating

\begin{tabular}{lcc}
\hline & t-statistics & f square \\
\hline Governance -> Green Compliance & 0.934 & 0.034 \\
Firm-Specific -> Green Compliance & $1.978^{* *}$ & 0.054 \\
Green Compliance -> Benefits & $3.763^{* *}$ & $0.170^{*}$ \\
\hline
\end{tabular}


In the literature, we found that some researchers (Clark, 2015; Dialysa, 2015; Radu, 2012; Iraldo et al., 2009; Amore et al., 2015; Bunget et al., n.d.) indicated a relationship between good governance and better environmental performance. In line with this, independent directors positive association with the board provides support for hypothesis H1b, which is also backed by many other studies (Mittal, 2011, De Andres \& Vallelado, 2008, Shakir, 2008). According to the guidelines of the 2014 Bangladesh Bank Code of Governance, the recommended size of the board is $7-15$ directors. On average, boards comprise 14 members from both Islamic and conventional banks, with an average of two independent directors, as shown in Table 2. In the case of Bangladesh, the concept and implementation of independent directors are not executed at their full potential in the banking sector. Therefore, hypotheses $1,1 \mathrm{a}$ and $1 \mathrm{~b}$ are accepted.

The results are shown in Figure 2, and Table 6 provide a clear indication that the firm-specific variable positively affects the extent of green compliance among the selected banks. Therefore, hypothesis 2 is accepted. Based on the regression results presented in Table 7 , we can conclude that size has a significant positive association with the extent of green compliance in the case of the full sample and that of conventional banks only. At the same time, independent directors are a positively significant predictor of green compliance for both Islamic and conventional banks. Age was not found to have a significant association with green compliance in any of the models. These results prove that bigger companies have greater motivation to go green. Therefore, hypotheses $2 b$ and $2 c$ are accepted.

Finally, the association between the extent of green compliance and the expected benefits were investigated, which is the prime focus of this study. Based on the results shown in Figure 2 and Table 6, it can be concluded that the extent of green compliance has a positive impact on the level of benefits that can be attained by the banking industry. The results are consistent with the full sample (all 40 scheduled banks), conventional banks only (32 banks) and Islamic banks only (eight banks). Only profitability shows little association. These results are consistent because of some of the new banks started their operations after 2015 and 2017, where they were still at the survivor stage. The results are also widely supported in the literature.

In the literature, it has been seen that accountability has a very positive relationship with green banking, with the strict surveillance of Bangladeshi banks, perhaps being a good reason for this. Reputation is one of the significant benefits that encourages both Islamic and conventional banks in Bangladesh. In contrast, the moral ground is more applicable to Islamic banks. The GLM test results in Table 8 confirm that the extent of green compliance has a significant positive association with reputation, accountability and moral ground. As such, hypotheses 3a, 3b, and $3 \mathrm{~d}$ are accepted. No such association was found between profitability and the benefits of green compliance. However, the government of Bangladesh is helping banks through a refinancing scheme. Therefore, hypothesis $3 \mathrm{c}$ is rejected.

The difference in the results between Islamic and conventional banking in the various tests generated the possibility of a moderating effect of the nature of the banks. As a result, a difference in slope test was conducted to determine whether the association two variables was higher for Islamic banks than for conventional 
ones. As previously discussed, a moderating test was performed for all the paths in the structural model. However, only the path from green compliance to the outcome was found to be significant. As a result, we can conclude that the level of benefits attained through green compliance is higher for Islamic banks than for conventional ones.

\section{CONCLUSION AND RECOMMENDATIONS}

\subsection{Conclusion}

Green banking in Bangladesh has focused on developing a culture within organisations based on governance in order to adopt national and international best practice and to share know-how with peer groups. In our research model, we incorporated the underlying causes, both governance-related and firm-specific, with the green banking compliance index and examined the significance level of several benefits, namely accountability, profitability, reputation and moral ground. In the first phase of the examination, it was seen that firm-specific factors had a positive association with the green compliance index, whereas governance was not significantly associated. Governance is a fairly new concept in the banking industry, so we believe it will take some time to make its mark on the green compliance scenario. Although not significantly associated, the indicators used to measure the level of governance identified some basic relationships. On the other hand, independent directors have a very influential effect on compliance with green banking issues, which can create potential scope for policymakers to emphasise the inclusion of the right proportion of independent directors on boards. Furthermore, green compliance is also positively associated with the underlying results, which means that if banks comply with green policies, they will gain more benefits, which will increase their accountability, reputation and particularly their moral ground. Only profitability receives slightly less attention, which may be explained by banks' reluctance to spend more money on items which do not directly generate revenue. These results statistically support our expectations regarding green compliance scenarios for both Islamic and conventional banks in Bangladesh. As expected, moral ground is rated highly by Islamic banks, which is in accordance with the Islamic view. In the second phase of our examination, we found that among the three hypotheses, only execution of green banking provided more benefits to Islamic banks than conventional ones. The first two hypotheses did not have such significant consequences for Islamic banks than conventional banks. Green banking creates more advantages which are supported by Islamic principles. Overall, green banking is backed by Islamic Shariah law. The majority of the Bangladeshi population is Muslim, so it is expected that consumers of Islamic banking will have a greater sensitivity toward Shariah principles and support Islamic bank initiatives in going green. The World Bank has already predicted that the effects of climate change will be higher for developing countries such as Bangladesh. Therefore, a mix of Islamic and green concepts in Bangladesh, with commercial banks, would undoubtedly add more value to end-users, as well as create a viable future for the country. 


\subsection{Recommendations}

As discussed earlier, the study found that the level of benefits attained by banks through green compliance is higher for Islamic banks than for conventional ones. In order to gain maximum benefits, policymakers need to introduce effective mechanisms to support the implementation of green banking. As people have more faith in Shari'ah-based banking, more products can be offered in this area to increase market share. Strong surveillance and monitoring systems by the authorities need to be in place in the utilisation of all received funds. The regulatory bodies should play a proficient role and have no option to neglect or become lenient with noncompliers. Bangladesh Bank needs to give more emphasis on conducting further research on these issues. It should offer more subsidies to banks to implement green banking. Some of the recommendations about green policies are listed below:

Banks should provide green loans to develop environmentally friendly homes and industries. When the question of energy-efficient home arises, people tend to think only about solar panels. However, there are other efficient ways available to create more environmentally friendly homes, such as cool roofing; water-saving irrigation systems; heating and cooling systems, such as central air-conditioning and smart thermostats; window upgrades; insulation improvements; use of Energy Star appliances, such as dishwashers, refrigerators and washing machines; LED lighting; pool pumps; and landscaping.

Banks should also develop and provide more green credit cards to customers. These can be a tech-tool to screen and deal with the utilisation of merchandise and enterprises that radiate ozone-harming substances. Green credit card clients could be awarded e-points, which could be changed into money or donated to ecological development funds when they purchase eco-accommodating items, use public transport, make paperless exchanges, or consume less energy, water and gas. Such cards may offer scope for electric vehicle charging services and the acquisition of reused car parts. Moreover, they may sustain the market for low-carbon items and services, subsequently driving eco-advancement and the move to a low-carbon economy.

Mobile banking and internet banking can play a vital role in paperless transections and green banking. Nowadays, the use of mobile banking has made a significant change in terms of paperless transactions. However, there remain gaps related to security issues, which must be made more constructive, secure and strict. The regulatory bodies must pay attention to these initiatives carefully.

Banks could develop Remote Deposit Capture (RDC) services for their clients. This is a framework that enables clients to examine cheques remotely and send pictures of them to banks for a deposit, usually via an encrypted internet connection. When the bank receives a check picture from the client, it deposits into the client's account. It makes the funds accessible, depending on the client's specific accessibility plan. RDC encourages eco-friendly services with fewer system errors.

Researchers should develop innovations and ideas in terms of eco-friendly products and go-green products. The central bank could arrange competitions to encourage the innovation of new green products and services, or to reform existing products or services to make them eco-friendly. 
Banks should provide specific chapters on green banking in their annual reports, which should include green exercises, such as the areas in which specific costs have decreased for the non-usage of carbon footprints; where and how the expenditure on green products is measured; and how much extra revenue innovative green products can generate. This information would help monitor the system and go-green policies and also add value to people in general and to those who intend to conduct specific research on the topic of green banking.

The government should introduce tax exemptions in some particular cases of green banking for two years; e.g., in the case of green credit cards, green loans and green projects. Moreover, the government should award financial institutes for effecting green policies.

To enjoy the benefits of the Islamic concept, conventional banks in Bangladesh should open more Islamic branches, where clients can relate green initiatives more closely with Islam. Meanwhile, banks that still have not adopted their own separate green cells should complete the process, and regulators must continue monitoring the development on time.

\section{REFERENCES}

Ahmad, F., Zayed, N.M., \& Harun, M.A. (2013). Factors Behind the Adoption of Green Banking by Bangladeshi Commercial Banks. ASA University Review, 7(2), 241-255.

Alina, T., Correlation Between Corporate Governance and Financial Performance. Retrieved September 16, 2018, from http://www.dafi.ase.ro/revista/8/ Tucaliuc\%20Alina \%20DAFI\%20-\%20Correlation \%20between \% 20 Corporate\%20Governance\%20and\%20Financial\%20Performance.pdf.

Amore, M.D., Bennedsen, M., \& Nielsen, K. (2015). Return to Political Power in a Low Corruption Environment. INSEAD Working Paper No. 2015/80/EPS, Available at SSRN: https://ssrn.com/abstract=2666087 or http://dx.doi.org/10.2139/ ssrn. 2666087

Anderson, E.W., \& Fornell, C. (2009). Foundations of the American Customer Satisfaction Index. Total Quality Management, 11(7), 869-82.

Andrade da Silva, J., \& Cernat, L. (2012). Coping with Loss: the Impact of Natural Disasters on Developing Countries' Trade Flows. DG TRADE Chief Economist Note. doi: 10.13140/2.1.1950.7843. Available at: https://www.researchgate. net/profile/Lucian_Cernat/publication/264194255_Coping_with_loss_ the_impact_of_natural_disasters_on_developing_countries'_trade_flows/ links/53d136af0cf220632f3925b4.pdf.

De Andres, P., \& Vallelado, E. (2008). Corporate Governance in Banking: The Role of the Board of Directors. Journal of Banking \& Finance, 32(12), 2570-2580.

Bagozzi, R.P., \& Yi, Y. (1991). Multitrait-multimethod Matrices in Consumer Research. Journal of Consumer Research, 17(4), 426-39.

Bangladesh Bank. (2011). Bangladesh Bank BRPD Circular No-2.

Bangladesh Bank. (2012). Bangladesh Bank Annual Report.

Bangladesh Bank. (2016). Are We Greening the Economy? Working paper. Retrived August 7, 2018, from https://www.bb.org.bd/pub/research/workingpaper/ wp1618.pdf. 
Bangladesh Bank. (2017). Reporting Green Banking Activities under Phase II. Retrived August 7, 2018, from. https://www.bb.org.bd/pub/quaterly/greenbanking/ greenbanking_octdec2017.pdf.

Bangladesh Bank. (2018). Bangladesh Bank Annual Report, Retrived August 11, 2018, from https://www.bb.org.bd/pub/annual/anreport/ar1819/index1819.php

Bangladesh Bureau of Statistics (2014). GDP of Bangladesh 2014-2015, Available at: $\quad$ http://www.bbs.gov.bd/WebTestApplication/userfiles/Image/GDP/ GDP_2014_5\%28p\%29.pdf.

Barclay, D., Higgins, C. \& Thompson, R. (1995). The Partial Least Squares (PLS) Approach to Causal Modelling: Personal Computer Adoption and Use as an Illustration. Technology Studies, Special Issue on Research Methodology, 2(2), 285309.

Becker, J. M., \& Ismail, I. R. (2016). Accounting for Sampling Weights in PLS Path Modeling: Simulations and Empirical Examples. European Management Journal, 34(6), 606-617.

Benedikter, R. (2011). Social Banking and Social Finance. New York, NY: Springer.

Vizcaino, Bernardo. (2014). Islamic Finance Seeks to Go Green with Environmentbased Products. Reuters. Available at: http://uk.reuters.com/article/uk-islambanking-agriculture-idUKKBN0GX0D520140902.

Bhardwaj, B.R., \& Malhotra, A. (2013). Green Banking Strategies: Sustainability Through Corporate Entrepreneurship. Greener Journal of Business and Management Studies, 3(4), 180-193.

Bose, S., Khan, H. Z., Rashid, A., \& Islam, S. (2018). What Drives Green Banking Disclosure? An Institutional and Corporate Governance Perspective. Asia Pacific Journal of Management, 35(2), 501-527.

Biswas, N. (2011). Sustainable Green Banking Approach: The Need of the Hour. Business Spectrum, 1(1), 32-8. 38-40.

Brammer, S. \& Pavelin, S. (2008). Factors Influencing the Quality of Corporate Environmental Disclosure. Business Strategy and the Environment, 17(2), 120136.

Brown, N. \& Deegan, C. (1998). The Public Disclosure of Environmental Performance Information-a Dual Test of Media Agenda Setting Theory and Legitimacy Theory. Accounting and Business Research, 29(1), 21-41.

Bunget, O. C., Florea-Ianc, Z., Ghiţă, M., Nicolau, C., Pereş, C. E., \& Pereş, I. (2009). Corporate governance and internal audit.

Chin, W.W. (1998). Issues and Opinion on Structural Equation Modeling. MIS Quarterly, 22(1), 7-16.

Chintaman, S. A. (2014). A Comparative Study of CSR Practices of Islamic Banks and Conventional Banks in GCC Region. Journal of Islamic Banking and Finance, 2(1), 1-21.

Clark, M. T. (2010). Governance Challenges in Financing Green and Sustainable Energy Policies. Friedrich-Ebert-Stiftung, Global Policy and Development.

De Villiers, C., Naiker, V., \& van Staden, C.J. (2011). The Effect of Board Characteristics on Firm Environmental Performance. Journal of Management. 37(6), 1636-1663. 
Dialysa, F. (2015). Green Banking : One Effort To Achieve The Principle Of Good Corporate Governance (GCG). In First International Conference on Economics and Banking (ICEB-15), 128-132.

Eccles, R.G., Ioannou, I., \& Serafeim, G. (2011). The Impact of a Corporate Culture of Sustainability on Corporate Behavior and Performance. Harvard Business School Working Paper, 12-035.

Ali, E., \& Rahman, S. M. (2015). Corporate social responsibility disclosure: A comparative study between Islamic banks and conventional banks in Bangladesh. International Business and Management, 10(1), 9-17.

EC-European Commission. (2011). Green Paper on the EU Corporate Governance Framework. European Commission Communication.

Ferdous, A.S., \& Polonsky, M.J. (2013). Predicting Bangladeshi Financial Salespeople's Ethical Intentions and Behaviour Using the Theory of Planned Behaviour - Implications for Developing Countries. Asia Pacific Journal of Marketing and Logistics, 25(4), 655-673.

Forker, J.J. (1992). Corporate Governance and Disclosure Quality. Accounting and Business Research, 22(86), 111-124.

Fornell, C., \& Lacker, D.F. (1981). Structural equation models with unobservable variables and measurement error: Algebra and statistics. Journal of Marketing Research, 18(1), 39-50.

Garg, S. (2015). Green Banking: An Overview. Global Journal of advance research, 2(8), 1291-1296.

Gaskin, J. (2016). X2 Difference. Stats Tools Package. http://statwiki. kolobkreations. com.

Gefen, D., Straub, D.W., \& Boudreau, M.-C. (2000). Structural Equation Modeling and Regression: Guidelines for Research Practice. Communications of the Association for Information Systems, 4, 1-79.

Gil-Garcia, J.R. (2008). Using Partial Least Squares in Digital Government Research. Handbook of Research on Public Information Technology. Hershey, PA: Idea Group, 239-53.

Goyal, K. A., \& Joshi, V. (2011). A study of social and ethical issues in banking industry. International Journal of Economics and Research, 2(5), 49-57.

Hair, J., Black, W., Babin, B., Anderson, R., \& Tatham, R. (2010). Multivariate Data Analysis. Upper Saddle River, N.J: Pearson Prentice Hall.

Hair, J. F., Hult, G. T. M., Ringle, C. M., \& Sarstedt, M. (2017). A Primer on Partial Least Squares Structural Equation Modeling (PLS-SEM), 2nd Ed., Thousand Oaks, CA: Sage.

Hasan, R., \& Miah, M. D. (2018). Intellectual Capital and Firm Performance: Evidence from the Financial Sector in Bangladesh. International Journal of Accounting and Finance, 8(2), 133-150.

Henseler, J., Ringle, C. M., \& Sarstedt, M. (2015). A New Criterion for Assessing Discriminant Validity in Variance-based Structural Equation Modeling. Journal of the Academy of Marketing Science, 43(1): 115-135.

Hossain, D. M., Bir, A., Sadiq, A. T., Tarique, K. M., \& Momen, A. (2016). Disclosure of Green Banking Issues in the Annual Reports: A Study on Bangladeshi Banks. Middle East Journal of Business, 11(1), 19-30. 
Hossain, M. S., \& Kalince, M. T. A. (2014), Green banking bexus banks' performance. Swiss Journal of Research in Business and Social Science, 1(3), 1-16.

International Environment House, (2011). United Nations Environment Program Finance Initiative, Switzerland. http://www.unepfi.org/fileadmin/documents/ UNEPFI_Brochure_Web.pdf.

Iraldo, F., Testa, F., \& Frey, M. (2009). Is an Environmental Management System Able to Influence Environmental and Competitive Performance? The Case of the Eco-management and Audit Scheme (EMAS) in the European Union. Journal of Cleaner Production, 17, 1444-1452.

Islam, M. A., Hossain, K. F., Siddiqui, M. H., \& Yousuf, S. (2014). Green-Banking Practices in Bangladesh - A Scope to Make Banking Green. International Finance and Banking, 1(1), 1-38.

Islam, M.S. (2014). Green Banking in Bangladesh: How Much Implemented by the Practitioners? Abasyn University Journal of Social Sciences, 7(2). 189-210.

Jeucken, M. (2001). Sustainable Finance and Banking: The Financial Sector and the Future of the Planet, London: Earthscan.

Jolliffe, D., Sharif, I., Gimenez, L., \& Ahmed, F. (2013). Bangladesh-Poverty Assessment: Assessing a Decade of Progress in Reducing Poverty, 20002010. Bangladesh Development Series Paper, (31).

Khan, K.R. (2003). Awqaf Laws in the South Asia and South East Asia - A Comparative Study. In International Seminar on Awqaf Experiences in Brunei, Indonesia, Kuwait and Pakistan. Islamabad, 15 - 18.

Lalon, R.M. (2015). Green Banking: Going Green. International Journal of Economics, Finance and Management Sciences, 1, 34-42.

Laskowska, A. (2018). Green Banking as the Prospective Dimension of Banking in Poland. Ecological Questions, 29(1), 129-135.

Lowry, P.B., \& Gaskin, J. (2014). Partial Least Squares (PLS) Structural Equation Modeling (SEM) for Building and Testing Behavioral Causal Theory: When to Choose it and How to Use it. IEEE Transactions on Professional Communication, 57(2), 123-146.

Masukujjaman, M., Siwar, C., Mahmud, M. R., \& Alam, S. S. (2017). Bankers' Perception of Green Banking: Learning from the Experience of Islamic banks in Bangladesh. Geografia-Malaysian Journal of Society and Space, 12(2). 144-153.

McCammon, A.L.T. (1995), Banking Responsibility and Liability for the Environment: What are Banks Doing? Environmental Conservation, 22(4), 297305.

Meena, R. (2013). Green Banking: As initiative for sustainable development. Global Journal of Management and Business Studies, 3(10), 1181-1186.

Miah, M. D., Rahman, S. M., \& Haque, M. (2018). Factors Affecting Environmental Performance: Evidence from Banking Sector in Bangladesh. International Journal of Financial Services Management, 9(1), 22-38.

Millat, K. M., Chowdhury, R., \& Singha, E. A. (2013). Green Banking in Bangladesh: Fostering Environmentally Sustainable Inclusive Growth Process. Department of Communications and Publications, Bangladesh Bank.

Mittal, P. (2011). The Role of Independent Directors in Corporate Governance. National University of Juridical Sciences Law Review, 4, 285-298. 
Nath, V., Nayak, N. \& Goel, A. (2014). Green Banking Practices - A Review. International Journal of Research in Business Management, 2(4), 45-62.

Neu, D., Warsame, H. \& Pedwe, K. (1998). Managing Public Impressions: Environmental Disclosures in Annual Reports. Accounting, Organizations and Society, 23(3), 265-282.

Nunnally, J. C. (1978). Psychometric theory. New York: McGraw-Hill Inc.

Nunnally, J. C., \& Bernstein, I. H. (1994). Psychometric theory. New York: McGrawHill

Oyegunle, A., \& Weber, O. (2015). Development of Sustainability and Green Banking Regulations: Existing Codes and Practices. Centre for International Governance Innovation. Waterloo, Ontario, Canada.

Papastergiou, A., \& Blanas, G. (2011). Sustainable Green Banking: The case of Greece. In Management of International Business and Economics Systems (MIBES) Conference. 2011, 204-215.

Patten, D.M. (2002). The Relation between Environmental Performance and Environmental Disclosure: a Research Note. Accounting, Organizations and Society, 27(8), 763-773.

Purushothaman, M. A. Y. A., Tower, G., Hancock, P., \& Taplin, R. (2000). Determinants of Corporate Social Reporting Practices of Listed Singapore Companies. Pacific Accounting Review, 12(2), 101.

Radu, M. (2012). Corporate Governance, Internal Audit and Environmental Audit - The Performance Tools in Romanian Companies. Accounting and Management Information Systems, 11(1), 112-130.

Rahman, M., Ahsan, M., Hossain, M., \& Hoq, M. (2013). Green Banking Prospects in Bangladesh. Asian Business Review, 2(4), 59-63.

Ramnarain, T. D., \& Pillay, M. T. (2016). Designing Sustainable Banking Services: The Case of Mauritian Banks. Procedia-Social and Behavioral Sciences, 224, 483490.

Rashid, M. (2010). Green Banking Comes to Focus. The Daily Star. Available at: http://www.thedailystar.net/newDesign/newsdetails.php?nid=154690.

Saha, P. (2013). Developing Green Banking Products In Bangladesh: Involvement of Stakeholders, Munich, GRIN Verlag, https://www.grin.com/document/212687

Shakir, R. (2008). Board Size, Board Composition And Property Firm Performance. Pacific Rim Property Research Journal, 14(1), 1-16.

Sharmeen, K., Hasan, R., \& Miah, M. D. (2019). Underpinning the Benefits of Green Banking: A Comparative Study between Islamic and Conventional Banks in Bangladesh. Thunderbird International Business Review, 61(5), 735-744.

Singh, Y. (2015). Environmental Management Through Green Banking: A Study of Commercial Banks in India. International Journal of Interdisciplinary and Multidisciplinary Studies, 2(4), 17-26.

Ramnarain, T. D., \& Pillay, M. T. (2016). Designing Sustainable Banking Services: The Case of Mauritian Banks. Procedia-Social and Behavioral Sciences, 224, 483490.

Sreesha, C. (2014). A Study on Green Banking Initiatives of Selected Private and Public Sector Banks in India. International Journal of Research, 1(7), 807-814. 
Suzuki, Y., \& Miah, M. D. (2016). Altruism, Reciprocity and Islamic Equity Finance. International Journal of Islamic and Middle Eastern Finance and Management, 9(2), 205-221.

Tavakol, M., \& Dennick, R. (2011). Making Sense of Cronbach's Alpha. International Journal of Medical Education, 2, 53-55.

Ullah, M.M. (2013). Green Banking in Bangladesh-A Comparative Analysis. World Review of Business Research, 3(4), 74-83.

Uyar, A., Kilic, M., \& Bayyurt, N. (2013). Association between Firm Characteristics and Corporate Voluntary Disclosure: Evidence from Turkish Listed Companies. Intangible Capital, 9(4), 1080-1112.

World Bank. (2013). Turn down the heat: Climate extremes, regional impacts, and the case for resilience. A Report for the World Bank by the Potsdam Institute for Climate Impact Research and Climate Analytics. Available at: http://www. worldbank.org/content/dam/Worldbank/document/Full_Report_Vol_2_ Turn_Down_The_Heat_\%20Climate_Extremes_Regional_Impacts_Case_for_ Resilience_Print\%20version_FINAL.pdf.

Yadav, R., \& Pathak, G.S. (2013). Environmental Sustainability through Green Banking: A Study on Private and Public Sector Banks in India. OIDA International Journal of Sustainable Development, 6(8), 37-48.

Zadek, S., \& Robins, N. (2015), Aligning the Financial System with Sustainable Development. Geneva, Switzerland: UNEP. 


\section{APPENDIX 1}

Appendix 1.

\section{Green Banking Checklist based on Bangladesh Bank Circular}

\begin{tabular}{llll}
\hline 1. Policy Formulation and Governance & \multicolumn{2}{c}{ Year } \\
\hline $\begin{array}{l}\text { 1.1 Formulation and Board/Regional Head approval of green banking policy } \\
\text { as per the direction of Bangladesh Bank. }\end{array}$ & Yes & No
\end{tabular}

1.2 Amount of funds received from Bangladesh Bank for green banking purposes (in million taka)

1.3 Allocation of funds in the budget for green banking (in million taka) Amount

1.4 Utilization of funds (in million taka) Amount

$\begin{array}{lll}1.5 \text { Formation of green banking unit } & \text { Yes No }\end{array}$

2. Incorporation of Environmental Risk in Core Risk Management (CRM)

2.1 No. of projects applicable for Environmental Due Diligence (EDD) Quantity

3. Initiating of In-house Environment Management

3.1 No. of branches and booths

Quantity

3.2 No. of branches powered by solar energy

Quantity

3.3 No. of booths powered by solar energy

Quantity

3.4 Introduction of green office guide or general instructions

3.6 Inventory Details

3.6.1 Consumption of water (in million taka)

Amount

3.6.2 Consumption of paper (in million taka)

Amount 


\section{Appendix 1. \\ Green Banking Checklist based on Bangladesh Bank Circular (Continued)}

\section{Utilization of Climate Risk Fund}

4.1 Fund for part of CSR activities (events) related to climate change (in million taka)

Amount

\section{Introducing Green Marketing}

5.1 Introduction of green banking products (please specify)

Yes

No

6. Employee Training, Consumer Awareness, and Green Events

6.1 No. of training programs/seminars /workshops/ awareness programs exclusively conducted for green banking

Quantity

6.1.1 Name of the program type with numbers (example: one workshop, two seminars)

6.2 Green Events (please specify)

Quantity

\section{Disclosure of Green Banking Activities}

7.1 Disclosure in annual report

Yes

No

7.2 Disclosure on website

Yes

No

7.3 Disclosure in the media

Yes

No

7.4 Preparation of independent green banking and sustainability report

Yes

No 
Appendix 2.

Green Banking Compliance Index (GCI)

\begin{tabular}{|c|c|c|c|c|c|}
\hline SL & Bank & Phase 1 & Phase 2 & Phase 3 & TPS \\
\hline \multicolumn{6}{|c|}{ Conventional Bank } \\
\hline 1 & $\mathrm{AB}$ bank & $85.71 \%$ & $40.00 \%$ & $0.00 \%$ & $41.90 \%$ \\
\hline 2 & Bangladesh Commerce Bank Limited & $85.71 \%$ & $60.00 \%$ & $50.00 \%$ & $65.24 \%$ \\
\hline 3 & Bank Asia Limited & $85.71 \%$ & $80.00 \%$ & $50.00 \%$ & $71.90 \%$ \\
\hline 4 & Brac Bank limited & $71.43 \%$ & $40.00 \%$ & $100.00 \%$ & $70.48 \%$ \\
\hline 5 & Dhaka Bank Limited & $100.00 \%$ & $60.00 \%$ & $0.00 \%$ & $53.33 \%$ \\
\hline 6 & Dutch Bangla Bank Limited & $85.71 \%$ & $80.00 \%$ & $50.00 \%$ & $71.90 \%$ \\
\hline 7 & Estern Bank Limited & $100.00 \%$ & $80.00 \%$ & $100.00 \%$ & $93.33 \%$ \\
\hline 8 & IFIC Bank Limited & $100.00 \%$ & $80.00 \%$ & $50.00 \%$ & $76.67 \%$ \\
\hline 9 & Jamuna Bank Limited & $85.71 \%$ & $80.00 \%$ & $100.00 \%$ & $88.57 \%$ \\
\hline 10 & Meghna Bank & $57.14 \%$ & $20.00 \%$ & $0.00 \%$ & $25.71 \%$ \\
\hline 11 & Mercantile Bank Limited & $100.00 \%$ & $80.00 \%$ & $50.00 \%$ & $76.67 \%$ \\
\hline 12 & Midland Bank & $85.71 \%$ & $80.00 \%$ & $50.00 \%$ & $71.90 \%$ \\
\hline 13 & Modhumoti Bank Limited & $42.86 \%$ & $80.00 \%$ & $100.00 \%$ & $74.29 \%$ \\
\hline 14 & Mutual Trust Bank & $100.00 \%$ & $80.00 \%$ & $50.00 \%$ & $76.67 \%$ \\
\hline 15 & National Bank Limited & $100.00 \%$ & $60.00 \%$ & $0.00 \%$ & $53.33 \%$ \\
\hline 16 & National Credit \& Commerce Bank Limited & $100.00 \%$ & $60.00 \%$ & $50.00 \%$ & $70.00 \%$ \\
\hline 17 & NRB Bank Limited & $100.00 \%$ & $80.00 \%$ & $50.00 \%$ & $76.67 \%$ \\
\hline 18 & NRB Commercial Bank Limited & $85.71 \%$ & $80.00 \%$ & $100.00 \%$ & $88.57 \%$ \\
\hline 19 & NRB Global Bank Limited & $71.43 \%$ & $40.00 \%$ & $0.00 \%$ & $37.14 \%$ \\
\hline 20 & One Bank Limited & $57.14 \%$ & $40.00 \%$ & $0.00 \%$ & $32.38 \%$ \\
\hline 21 & Premier Bank Limited & $85.71 \%$ & $40.00 \%$ & $100.00 \%$ & $75.24 \%$ \\
\hline 22 & Prime Bank Limited & $71.43 \%$ & $40.00 \%$ & $100.00 \%$ & $70.48 \%$ \\
\hline 23 & Pubali Bank Limited & $100.00 \%$ & $60.00 \%$ & $50.00 \%$ & $70.00 \%$ \\
\hline 24 & Shimanto Bank Limited & $57.00 \%$ & $40.00 \%$ & $50.00 \%$ & $49.00 \%$ \\
\hline 25 & South Bangla Agriculture and Commerce Bank & $57.14 \%$ & $60.00 \%$ & $100.00 \%$ & $72.38 \%$ \\
\hline 26 & Southeast Bank & $100.00 \%$ & $80.00 \%$ & $100.00 \%$ & $93.33 \%$ \\
\hline 27 & Standard Bank Limited & $85.71 \%$ & $80.00 \%$ & $100.00 \%$ & $88.57 \%$ \\
\hline 28 & The city bank Limited & $100.00 \%$ & $80.00 \%$ & $100.00 \%$ & $93.33 \%$ \\
\hline 29 & Trust Bank Limited & $100.00 \%$ & $60.00 \%$ & $50.00 \%$ & $70.00 \%$ \\
\hline 30 & United Commercial Bank Limited & $57.14 \%$ & $80.00 \%$ & $50.00 \%$ & $62.38 \%$ \\
\hline 31 & Uttara Bank Limited & $85.71 \%$ & $60.00 \%$ & $50.00 \%$ & $65.24 \%$ \\
\hline 32 & The Farmers Bank ${ }^{* * * * *}$ & $57.00 \%$ & $40.00 \%$ & $50.00 \%$ & $49.00 \%$ \\
\hline
\end{tabular}


Appendix 2.

Green Banking Compliance Index (GCI) (Continued)

\begin{tabular}{clrccc}
\hline SL & Bank & Phase 1 & Phase 2 & Phase 3 & TPS \\
\hline \multicolumn{7}{l}{1} & Al-Arafah Islami Bank Limited & $100.00 \%$ & $80.00 \%$ & $50.00 \%$ & $76.67 \%$ \\
2 & Exim Bank Limited & $85.71 \%$ & $80.00 \%$ & $100.00 \%$ & $88.57 \%$ \\
3 & First Security Islami Bank Limited & $100.00 \%$ & $80.00 \%$ & $100.00 \%$ & $93.33 \%$ \\
4 & ICB Islamic Bank Limited & $85.71 \%$ & $60.00 \%$ & $0.00 \%$ & $48.57 \%$ \\
5 & Islami Bank Bangladesh Limited & $85.71 \%$ & $80.00 \%$ & $50.00 \%$ & $71.90 \%$ \\
6 & Shahajalal Islami Bank Limited & $85.71 \%$ & $40.00 \%$ & $100.00 \%$ & $75.24 \%$ \\
7 & Social Islami Bank Limited & $85.71 \%$ & $80.00 \%$ & $50.00 \%$ & $71.90 \%$ \\
8 & Union Bank Limited & $85.71 \%$ & $60.00 \%$ & $50.00 \%$ & $65.24 \%$ \\
\hline \multicolumn{7}{r}{} & Average Score & & & \\
\hline & Conventional Banks & $83.03 \%$ & $63.13 \%$ & $57.81 \%$ & $67.99 \%$ \\
\hline
\end{tabular}

